\title{
EFEKTIVITAS SWEDISH MASSAGE TERHADAP KUALITAS TIDUR DAN TINGKAT INSOMNIA LANSIA
}

\author{
Rianayanti Asmira Rasam, Ressa Andriyani Utami \\ Sekolah Tinggi IImu Kesehatan RS Husada, Jakarta Pusat, DKI Jakarta, \\ Indonesia
}

\begin{abstract}
Abstrak
Latar belakang. Insomnia merupakan keluhan yang sering terjadi pada lansia, apabila tidak diatasi dapat menurunkan kualitas hidup lansia. Penanganan yang tepat dapat meningkatkan kualitas hidup lansia.

Tujuan Penelitian. Penelitian ini bertujuan untuk mengetahui efektivitas swedish massage terhadap kualitas tidur dan tingkat insomnia lansia.

Subjek dan Metode. Desain penelitian yang digunakan quasi experiment non equivalent control group pretest-post test. Jumlah sampel pada penelitian ini sebanyak 62 orang diambil secara random dibagi menjadi kelompok intervensi sebanyak 37 orang yang diberikan terapi swedish massage selama 7 hari dan kelompok kontrol sebanyak 25 orang diberikan terapi ibadah $2 x$ seminggu, sebelum dan sesudah intervensi dilakukan pengukuran tanda vital. Analisa penelitian menggunakan logistik binary dan uji beda $t$ test.

Hasil Penelitian. Hasil analisis logistik binary dan regresi linier berganda terdapat pengaruh signifikan antara terapi swedish masssage terhadap kualitas tidur pada hari ke 7 dan tingkat insomnia ( $p$ value $<0,05$ ).

Kesimpulan. Terdapat pengaruh swedish massage terhadap kualitas tidur dan tingkat insomnia lansia.
\end{abstract}

Kata kunci: insomnia, kualitas tidur, swedish massage

\section{THE EFFECT OF SWEDISH MASSAGE TO QUALITY OF SLEEP AND THE LEVEL OF INSOMNIA IN ELDERLY}

\begin{abstract}
Background. Insomnia is a complaint that often occurs in the elderly, if not resolved it can reduce the quality of life of the elderly. Proper handling can improve the quality of life of the elderly.

The Aim of The Study. This study aims to determine the effectiveness of Swedish massage on sleep quality and the level of insomnia in the elderly.

Subjects and Methods. The research design used quasi experiment non equivalent control group pretest-post test. The number of samples in this study were 62 people who were taken randomly, divided into an intervention group of 37 peoples who were given swedish massage therapy for 7 days and a control group of 25 peoples who were given worship therapy $2 x$ a week, before and after the intervention vital signs were measured. Research analysis using binary logistic and t test difference.

Results. The results of binary logistic analysis and multiple linear regression showed a significant effect between swedish massage therapy on sleep quality on day 7 and the level of insomnia ( $p$ value $<0.05$ ).

Conclusion. There is an effect of swedish massage on sleep quality and insomnia levels in the elderly.
\end{abstract}

Key words: insomnia, sleep quality, swedish massage

Korespondensi: Ressa Andriyani Utami, Sekolah Tinggi Ilmu Kesehatan RS Husada, Jalan Mangga Besar Raya 137-139, Jakarta Pusat, DKI Jakarta. 11730.

Email: ressa.andriyani.utami@gmail.com 
LATAR BELAKANG

Penuaan adalah suatu proses fisiologis yang dipengaruhi oleh faktor genetik dan lingkungan yang sifatnya alamiah. Penuaan bukanlah suatu penyakit tetapi merupakan proses alamiah yang menyebabkan perubahan fungsi fisiologis maupun psikologis. Populasi lansia dunia saat ini mengalami peningkatan yang signifikan. Proporsi penduduk dunia yang berusia lebih dari 60 tahun akan berlipat ganda dari sejumlah $11 \%$ menjadi $22 \%$ (World Health Organization, 2013). Di Indonesia pada tahun 2000 persentase populasi lansia $7,18 \%$ dengan umur harapan hidup 64,5 tahun dan pada tahun 2010 meningkat menjadi 69,43 (Depkes RI, 2013). Laju pertumbuhan lansia harus berbanding lurus dengan kewaspadaan terhadap kemungkinan gangguan kesehatan yang terjadi pada lansia. Masalah yang sering dialami lansia adalah gangguan tidur (Hellström, 2013).

Insomnia adalah kesulitan untuk istirahat tidur atau kesulitan untuk tetap tertidur atau gangguan tidur yang menyebabkan penderita merasa belum cukup tidur pada saat terbangun (Reed, et al., 2012). Tidur tidak teratur dan kejadian insomnia pada lansia dapat menyebabkan depresi, kecemasan, penurunan konsentrasi, risiko cedera jatuh, penurunan kognitif, gangguan memori, waktu respon melambat, penurunan kualitas hidup dan penurunan kinerja, sering terjadi misdiagnosis sebagai demensia bahkan dapat menyebabkan bunuh diri. Komplikasi sosial dapat terjadi pada lansia jika masalah tidur tidak tertangani, tidak bahagia, dicekam kesepian, dampak terhadap lingkungan serta keluarganya (Darmojo, 2010).

Terdapat beberapa cara untuk mengatasi permasalahan tidur dan insomnia pada lansia terutama intervensi non farmakologis antara lain dengan massage atau pijat. Pijat adalah metode berupa pemberian tekanan atau gesekan, atau membelai, menggosok, meremas, tapping, vibrating bagian luar tubuh dengan menggunakan tangan atau bahan lain seperti kain kasar dengan atau tanpa menggosok dengan minyak, krim dan salep. Salah satu teknik pijat adalah swedish massage. Terapi swedish massage membuat seseorang pulih dari nyeri, kecemasan, stres, relaksasi otot yang berkontribusi terhadap peningkatan kualitas tidur dan kesehatan secara keseluruhan. Cinar dan Eser (2012) melakukan penelitian dengan judul Effect on Sleep Quality of Swedish massage in Older Adults in Rest Home di Izmir, Turki. Sampel penelitian sebanyak 33 orang lansia diberikan terapi pijat punggung selama 10 menit sebelum lansia tidur selama tiga hari. Data penelitian dikumpulkan menggunakan kuesioner dari Pittsburgh Sleep Quality Index (PSQI). Hasil penelitian didapatkan skor PSQI total rata-rata sebelum pijat $(11,87 \pm$ $2,11)$ setelah pijat $(9,78 \pm 2,17) p$ value ( $t=8,07, p=0,000)$. Hasil penelitian ini menunjukkan bahwa pijat memiliki efek positif pada peningkatan kualitas tidur lansia.

Penelitian ini menggunakan konsep dan teori Virginia Henderson terkait kebutuhan tidur dan istirahat yang merupakan bagian dari empat belas kebutuhan dasar manusia yang apabila tidak terpenuhi akan mempengaruhi kondisi, fisiologis maupun psikologis manusia, menyebabkan kebutuhan dasar lainnya terganggu dan berakibat lanjut terhadap penurunan kualitas hidup bahkan membahayakan kesehatan maupun kehidupan manusia.

\section{TUJUAN PENELITIAN}

Penelitian ini bertujuan untuk menganalisis efektivitas swedish 
massage terhadap kualitas tidur dan tingkat insomnia lansia.

\section{METODE}

Penelitian ini menggunakan desain quasi eksperimental dengan desain non equivalent control group pre test-post test. Instrumen yang digunakan berupa lembar kuesioner dan lembar observasi, tensimeter air raksa merk Riester yang sudah dikalibrasi, stetoskop merk Riester, termometer digital dan jam tangan dengan kondisi baik. Kuesioner digunakan untuk mengumpulkan data karakteristik responden mencakup usia, jenis kelamin, tingkat pendidikan, kualitas tidur dan tingkat insomnia lansia. Kuesioner kualitas tidur di adaptasi dari Pittsburgh Sleep Quality Index (PSQI), kuesioner tingkat insomnia diadaptasi dari Pittsburgh Insomnia Rating Scale-20 Item Version (PIRS
20). Lembar observasi untuk pengukuran tanda-tanda vital (tekanan darah, suhu, pernafasan, nadi). Analisa penelitian menggunakan logistik binary dan uji beda $t$ test.

\section{SUBJEK}

Populasi pada penelitian ini adalah keseluruhan lansia di Panti Werdha Budi Mulia di Jakarta sebanyak 62 orang diambil secara random dibagi menjadi kelompok intervensi sebanyak 37 orang yang diberikan terapi swedish massage dan kelompok kontrol sebanyak 25. Penelitian ini dilaksanakan selama 1 minggu yaitu pada tanggal 13-19 November 2019 pada kelompok swedish massage, pada kelompok ibadah pelaksanaan penelitian dilakukan pada tanggal 20-27 November 2019.

\section{HASIL}

Hasil analisis univariat didapatkan data sebagai berikut:

Tabel 1.

Distribusi Frekuensi Responden Berdasarkan Usia

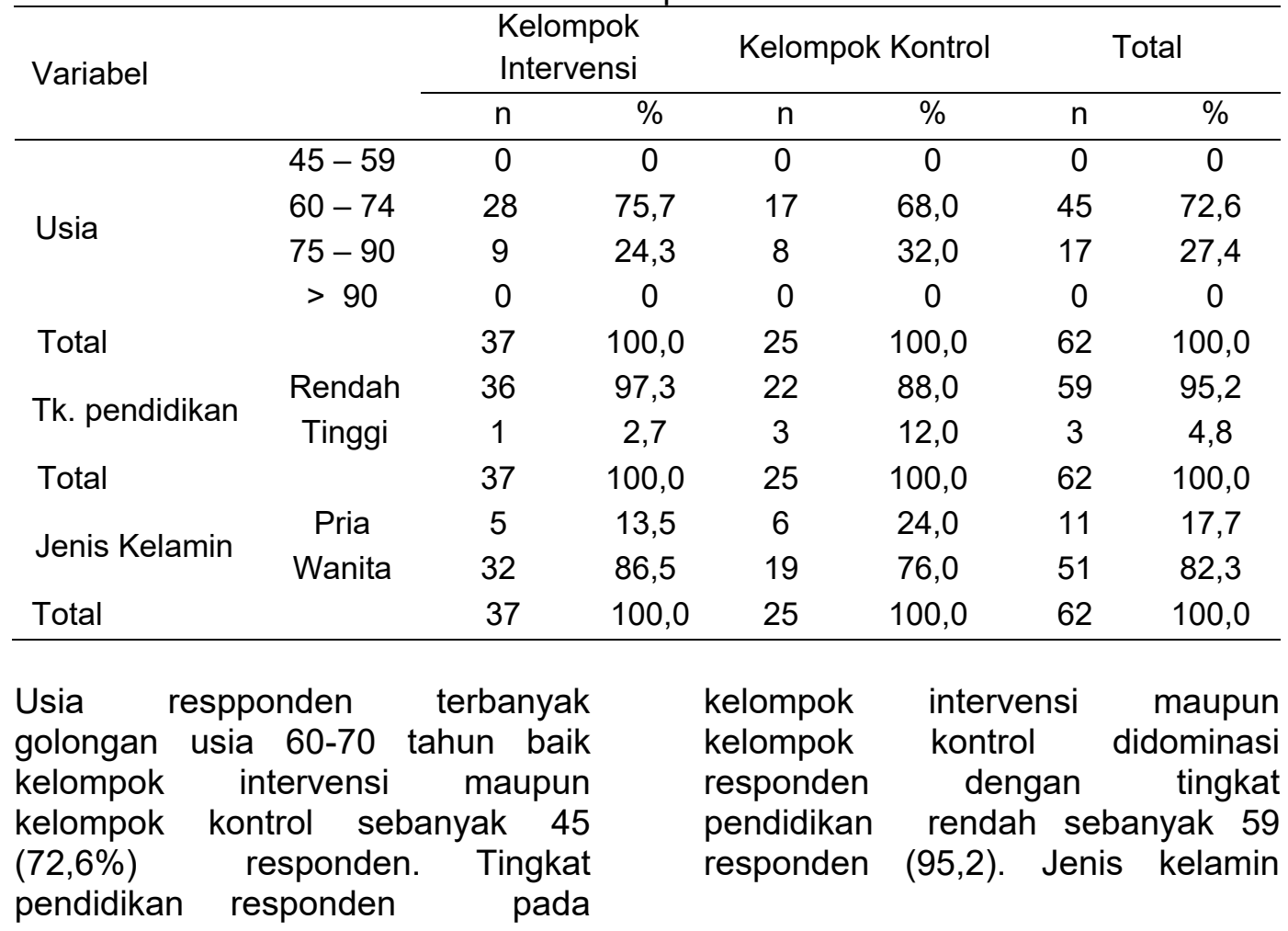


responden pada kelompok intervensi dan kelompok kontrol didominasi responden dengan jenis kelamin wanita sebanyak 51 responden $(82,3 \%)$.

Kualitas tidur responden pada hari I (pre intervensi) tidak terdapat selisih yang bermakna antara kelompok swedish massage dan kelompok ibadah, namun kualitas tidur pada hari ke VII (setelah intervensi) menunjukkan selisih rata-rata 0,55 .

Tingkat insomnia responden pada hari I (pre intervensi) tidak terdapat selisih yang bermakna antara kelompok swedish massage dan kelompok ibadah, namun tingkat insomnia pada hari ke VII (setelah intervensi) menunjukkan selisih rata-rata 12,19. Menurut PIRS 20 (Pittsburgh Insomnia Rating Scale20 Item Version) tingkat insomnia baik bila skor 0 , nilai semakin tinggi dengan skor 1 - 60 menunjukkan tingkat insomnia buruk.

Hasil analisis bivariat mengenai pengaruh intervensi Swedish message terhadap kualitas hidup dan tingkat insomnia lansia didapatkan data sesuai tabel berikut:

\section{Tabel 2.}

Analisis Uji Beda Kualitas Tidur dan Tingkat Insomnia Lansia Sebelum dan Sesudah Intervensi

\begin{tabular}{ccccc}
\hline & $\begin{array}{c}\text { kualitas } \\
\text { tidur } \\
\text { pre 1 }\end{array}$ & $\begin{array}{c}\text { kualitas } \\
\text { tidur } \\
\text { post 2 }\end{array}$ & $\begin{array}{c}\text { tingkat } \\
\text { insomnia } \\
\text { pre 1 }\end{array}$ & $\begin{array}{c}\text { tingkat } \\
\text { insomnia } \\
\text { post 2 }\end{array}$ \\
\hline $\begin{array}{c}\text { Asymp. } \\
\text { Sig. } \\
\text { (2-tailed) }\end{array}$ & 1,000 &, 000 & 1,000 &, 000 \\
\hline
\end{tabular}

Terdapat perbedaan yang signifikan terhadap kualitas tidur dan tingkat insomnia lansia sebelum dan setelah intervensi.

Pengukuran tanda vital (tekanan darah, suhu, nadi, pernafasan): pengukuran tanda vital dalam penelitian dilakukan sebelum dan sesudah intervensi selama 7 hari. Hasil uji beda tekanan darah sistolik terdapat perbedaan yang signifikan rata-rata penurunan tekanan darah sistolik sebelum dan sesudah dilakukan intervensi swedish massage setiap hari dengan nilai $p$ value $=0,000(p<0,05)$.

Hasil uji beda tekanan darah diastolik: terdapat perbedaan yang signifikan selisih rata-rata penurunan tekanan darah diastolik sebelum dan sesudah dilakukan swedish massage setiap hari dengan nilai $p$ value $=0,000$ $(p<0,05)$.

Hasil uji beda nadi: terdapat perbedaan yang signifikan penurunan rata- rata nadi sebelum dan sesudah dilakukan intervensi swedish massage setiap hari dengan nilai $p=0,000(p<0,05)$.

Hasil uji beda suhu tubuh: terdapat perbedaan yang signifikan selisih rata- rata peningkatan suhu sebelum dan sesudah dilakukan intervensi swedish massage setiap hari dengan nilai $\mathrm{p}$ value $=$ $0,000(p<0,05)$.

Hasil uji beda pernafasan: terdapat perbedaan yang bervariasi dari rata-rata hasil pengukuran pernafasan terutama pada hari ke IV terdapat selisih $-0,06$ yang bermakna terjadi peningkatan pernafasan setelah intervensi, sedangkan pada hari lainnya menunjukkan penurunan pada pengukuran pernafasan walaupun nilai signifinifikasinya bervariasi.

Hasil Analisis Regresi Linear Berganda mengacu pada Uji Signifikansi Parameter Individual (Uji statistik $\mathrm{t})$ : variabel swedish massage $(p=0,000)$ dan usia $(0,014)$ berpengaruh secara signifikan terhadap tingkat insomnia lansia setelah dilakukan intervensi hari ke 7 dengan $p$ value $<0,05$, sedangkan variabel jenis kelamin $(p=0,724)$ dan tingkat pendidikan 
$(p=0,791) \quad$ tidak berpengaruh terhadap kualitas tidur dengan pvalue $>0,05$.

Hasil Analisis Signifikansi Simultan didapatkan tingkat insomnia sesudah intervensi dengan probabilitas $0,000 \quad p<0,05$ menunjukkan setelah dilakukan intervensi, ke dua variabel independen (swedish massage dan usia) secara simultan berpengaruh terhadap tingkat insomnia lansia.

Hasil Analisis Koefisien Determinasi menunjukkan besarnya $R$ Square pada kelompok sesudah intervensi sebesar 0,711. Ini menunjukkan bahwa $71 \%$ variabel tingkat insomnia post intervensi dipengaruhi oleh variasi dari dua variabel independen (usia dan swedish massage ) sedangkan sisanya $29 \%$ $(100 \%$ - $71 \%)$ dijelaskan oleh sebab-sebab yang lain di luar model misalnya nokturia, faktor lingkungan, faktor psikologis dan gaya hidup.

Analisis Multivariat Regresi Logistik Binary (Regresi Logistik) menunjukkan hasil akhir menunjukkan variabel swedish massage $\quad(0,000)$ signifikan mempengaruhi kualitas tidur sedangkan variabel lain yaitu usia $(0,821)$, jenis kelamin $(0,490)$ dan tingkat pendidikan $(0,050)$ tidak signifikan mempengaruhi kualitas tidur.

\section{PEMBAHASAN}

Pijat telah lama dikenal memiliki efek meningkatkan relaksasi, memperbaiki pola tidur, meningkatkan kualitas tidur, membuat mood lebih stabil, meningkatkan fungsi mental, dan mengurangi kecemasan (University of Maryland Medical Center, 2013). Tujuan terapeutik lain dari pijat diantaranya dapat meningkatkan sirkulasi darah, relaksasi otot, mengurangi nyeri, pemulihan keseimbangan metabolik dan manfaat lainnya untuk fisik dan juga mental.
Hasil wawancara terhadap lansia setelah swedish massage hari terakhir $70 \%$ lansia mengatakan jam mulai tidur tidak ada perubahan tetapi waktu yang dibutuhkan untuk tertidur lebih singkat, tidur lebih nyenyak, terbangun di tengah malam jauh berkurang, badan terasa segar dan rasa kantuk di siang hari lebih berkurang. Selain berpengaruh terhadap kualitas tidur, swedish massage yang dilakukan berdampak memperbaiki sistem tubuh lainnya. Berdasarkan wawancara setelah swedish massage hari ke tujuh, 3 lansia menyampaikan kenyamanan lebih meningkat dikarenakan BAB lebih lancar, 4 lansia mengatakan makan lebih enak. Manipulasi yang diberikan dari bagian-bagian tubuh secara mekanis mendorong aliran darah pada pembuluh vena menuju ke jantung. Aliran darah yang lebih lancar dalam vena akan membantu kelancaran aliran darah pada arteri dan kapiler. Dengan demikian massage membantu proses penyerapan dan pembuangan sisasisa metabolisme dari dalam jaringan serta memperlancar distribusi nutrisi. Peningkatan sirkulasi memungkinkan penyerapan insulin lebih efektif. Hal ini juga berkaitan dengan aktifitas nervus vagus mempengaruhi penyerapan makanan. Penyerapan makanan akan lebih baik. Selain itu Pijat membantu meningkatkan fungsi sistem pencernaan dengan cara melepaskan ketegangan di otot-otot perut melepaskan ketegangan pada otot usus, mengurangi produksi gas, memperlancar pencernaan dengan merangsang peristaltik melepaskan enzim pencernaan menghilangkan sembelit.

Pengaruh usia terhadap kualitas tidur dan tingkat insomnia sedikit berbeda dibanding beberapa penelitian yang sudah dilakukan dimana sebagian besar 
menunjukkan usia lanjut mempengaruhi kualitas tidur.

Kondisi lingkungan di panti memberikan kontribusi penting bagi kualitas tidur lansia, suhu ruangan yang tidak dapat diatur secara personal, di panti tidak terdapat AC maupun kipas angin sehingga suhu lingkungan luar sangat mempengaruhi, penerangan yang tidak dapat diatur sesuai keinginan, dan tingkat kebisingan yang sulit di atasi karena lansia tinggal bersama dalam satu ruangan yang terbuka. Pada lansia secara fisiologis sering terbangun malam hari karena harus buang air kecil, kondisi ini menyebabkan meningkatnya tingkat insomnia karena setelah bangun lansia mengatakan memerlukan waktu > 30 menit untuk tertidur kembali. Nokturia didefenisikan oleh International Continence Society sebagai gangguan tidur 1 kali di malam hari atau lebih karena BAK. Nocturia umum terjadi pada lansia berusia tua dengan prevalensi $80-$ $90 \%$ pada lansia pria maupun wanita. Beberapa faktor yang dapat menyebabkan nokturia antara lain perubahan usia dan fungsi sistem perkemihan termasuk perubahan pada fungsi ginjal, intake cairan di malam hari sebelum tidur, dan pola kebiasaan berkemih. Nokturia yang terjadi pada lansia berkontribusi terhadap gangguan tidur dan tingkat insomnia lansia dikarenakan adanya interupsi saat tidur, membuat waktu terjaga lebih lama, yang pada akhirnya dapat mengganggu kualitas hidup lansia.

Keterbatasan kemampuan fisik menyebabkan lansia kurang beraktifitas dan kurang berolah raga di siang hari, lebih banyak berbaring di tempat tidur atau sesekali ngobrol dengan teman sesama lansia, yang menyebabkan kelelahan minimal dan berdampak kesulitan untuk tidur di malam hari. Tinggal di Panti Werdha bukanlah pilihan, sebagian besar lansia masih ingin tinggal bersama dengan keluarga, merasakan kehangatan dan kasih sayang dan perhatian dari pasangan, anak maupun cucu. Berbagai kondisi yang ada menyebabkan lansia harus tinggal di panti ; faktor sosial ekonomi, faktor support sistem yang tidak mendukung termasuk meninggalnya seluruh anggota seringkali dirasakan lansia sebagai kesepian yang menyebabkan rasa terisolasi yang pada akhirnya menyebabkan stres yang juga berkontribusi terhadap gangguan tidur pada lansia. Sekresi melatonin yang rendah dan menurunnya sensitivitas melatonin endogen pada lansia dianggap bertanggungjawab menyebabkan perubahan kualitas tidur pada lansia selain faktor lain seperti adanya gejala penyakit degeneratif, menopause yang menyebabkan simptom vasomotor (hot flushes, berkeringat malam) dan stres karena perubahan secara finansial, berkabung, dan kesepian (Canadian Sleep Society, 2012). The Nurse Practitioner: The American Journal of Primary Health Care (2010), insomnia pada lansia disebabkan oleh faktor internal maupun eksternal (Meridean, et al. 2011). Faktor internal secara fisiologis dapat mengganggu tidur antara lain gangguan siklus tidur yang berhubungan dengan penambahan usia, penyakit, nyeri, gangguan suhu tubuh, gangguan eliminasi, faktor psikologis karena stres dan kecemasan. Faktor eksternal sangat berdampak terhadap tingkat insomnia lansia lingkungan yang asing, peningkatan stimulasi sensorik, gaya hidup : perubahan dalam kebiasaan, menghabiskan waktu lebih banyak di tempat tidur, tidur siang berlebihan, dan olahraga yang kurang.

Jenis kelamin mendasari semua aspek yang berkaitan dengan kualitas tidur dan tingkat insomnia. 
Kualitas tidur perempuan paruh baya mengalami gangguan dikarenakan wanita memprioritaskan pasangan mereka dan tidur anakanaknya dibandingkan kebutuhan tidur mereka sendiri. Interaksi kerja fisik dan emosional terlibat dalam merawat bayi, anak-anak dan remaja dan kecemasan serta kekhawatiran yang terkait dengan tanggung jawab keluarga, pekerjaan, dan merawat orang tua, merupakan kompromi perempuan terhadap kualitas tidur mereka sendiri. Pada penelitian ini hasil analisis pengaruh faktor jenis kelamin terhadap penurunan tingkat insomnia lansia dengan menggunakan regresi logistik nominal menunjukkan jenis kelamin tidak berpengaruh terhadap kualitas tidur lansia dengan siginifikasi $p=0,490 \quad(p>0,05)$, dengan skor 0, 476 .

Berkaitan dengan hasil penelitian ada beberapa hal yang mendasari hasil uji tersebut antara lain peran dan fungsi pria sebagai kepala keluarga, pencari nafkah dan pengambil keputusan utama dan sebagian besar pemenuhan kebutuhan sehari - hari dilayani istri seperti umumnya peran pria di masyarakat tidak tampil pada lansia pria yang tinggal di panti, semua pria melakukan aktivitas sehari hari sama seperti lansia wanita. Begitu juga dengan lansia wanita yang tinggal di Panti Werdha semua pemenuhan kebutuhan sehari - hari yang umumnya di masyarakat dilakukan oleh wanita seperti memasak makanan untuk keluarga, mencuci pakaian dan membersihkan rumah di panti dilakukan oleh petugas panti. Semua kondisi tersebut dikhawatirkan menimbulkan bias pada penelitian ini.

Kualitas tidur lansia di panti banyak dipengaruhi faktor fisik dan lingkungan selain faktor penuaan yang berkontribusi terhadap kualitas tidur. Hal ini terjadi pada lansia, baik yang berpendidikan tinggi maupun rendah, sebagian besar lansia mengatakan memerlukan waktu yang lama untuk tertidur, waktu tidur yang singkat karena sudah terbangun dini hari, sering terbangun di malam hari karena buang air kecil, karena batuk atau mendengkur dan merasa suhu ruangan tidak nyaman, rendahnya aktivitas fisik karena keterbatasan kemampuan dan fasilitas yang tersedia membantu lansia memenuhi kebutuhan sehari - hari tanpa harus bekerja, memberikan dampak terhadap tidak signifikannya tingkat pendidikan terhadap kualitas tidur lansia.

Berdasarkan hasil wawancara setelah pemberian swedish massage hari ke tujuh sebagian besar mengatakan sudah lama sekali tidak merasakan ada pijatan di punggung dan merasa nyaman dengan pijatan yang diberikan, pegal - pegal di punggung lebih berkurang, merasa puas dengan tidurnya selama 1 minggu pemberian swedish massage, tidak mudah terbangun di malam hari, merasa lebih segar dan tidak mengantuk saat mengikuti pengajian mingguan, emosi lebih stabil dan tidak mudah marah.

Sejalan dengan pernyataan responden, terapi pijat yang merupakan gerakan menyentuh, membelai menggosok dan menekan dengan lembut dapat memberikan sensasi rasa menenangkan dan pengalaman yang menyenangkan. pijat memberikan respon fisiologis terintegrasi kepada hipothalamus yang menyebabkan penurunan respon terhadap ketegangan dari sistem saraf pusat menimbulkan relaksasi. Adanya relaksasi mengurangi kejang otot dan membantu menghilangkan rasa sakit. Studi menunjukkan bahwa pijat dapat digunakan untuk 
membantu masalah seperti kecemasan, stres, depresi, nyeri dan insomnia dengan mengurangi ketegangan pada otot. Efek yang paling populer dari pijat adalah untuk memberikan relaksasi psikologis, mengurangi kecemasan dan nyeri dan memberikan efek menyenangkan yang pada akhirnya dapat meningkatkan kepuasan terhadap tidur dan menurunkan gejala insomnia dalam CINAR \& ESER (2012).

Hasil penelitian ini sejalan dengan penelitian yang dilakukan oleh CINAR \& ESER (2012), yang dilakukan di Turki terhadap 300 lansia di Panti Werdha dilakukan swedish massage 10 menit selama 3 hari sebelum dilakukan swedish massage dilakukan pengukuran tanda vital, 15 dan 30 menit setelah swedish massage juga dilakukan pengukuran tanda vital. Hasil penelitian ini menunjukkan bahwa ada penurunan yang signifikan dari tekanan darah sitolik diastolik dan nadi segera setelah pijat punggung, berdasarkan hasil pengukuran tanda vital 15 menit dan 30 menit setelah swedish massage $(p<0,05)$ tetapi berbeda dengan suhu dan pernafasan tidak menunjukkan perbedaan yang signifikan.

Pijat meningkatkan tekanan pada jaringan. Menyebabkan gradien tekanan antara jaringan dan pembuluh akan meningkat dan memfasilitasi pergerakan cairan antara jaringan dan pembuluh dan sebaliknya. Kondisi tersebut menyebabkan terjadinya perubahan fisiologis misalnya pada tekanan darah. Pijat juga memberikan efek meningkatkan sirkulasi darah dan kelenjar getah bening, melepaskan respon saraf, melepaskan bahan kimia tubuh sehingga terjadi respon relaksasi. Dalam meningkatkan aktivitas sistem saraf parasimpatis yang mengeluarkan neurotransmiter asetilkolin yang dapat menghambat depolarisasi SA node dan AV node akibat aktivitas sistem saraf simpatis yang mengeluarkan neurotransmiter norepinephrin, hal ini menyebabkan terjadinya vasodilatasi sistemik dan penurunan kontraktilitas sehingga menimbulkan dampak penurunan kecepatan denyut jantung, curah jantung, dan volume sekuncup sehingga terjadi perubahan tekanan darah yaitu penurunan tekanan darah, masase juga menstimulasi menurunkan suhu tubuh, menurunkan level hormon stres diantaranya norepinephrin dan adrenalin.

Di sisi lain, pijat dapat mengalihkan perhatian pasien sehingga mengurangi kecemasan yang akhirnya dapat menurunkan tekanan darah dan denyut nadi. Pijat juga dapat menyebabkan pasien merasa nyaman rileks dan kemudian endorfin dapat disekresikan terjadi vasodilatasi yang berdampak meningkatkan aliran darah ke jaringan dan vasodilatasi juga akan menurunkan tekanan darah. Vasodilatasi pada pembuluh darah perifer di seluruh permukaan kulit mengantarkan rasa hangat pada suhu permukaan kulit juga berkontribusi terhadap kenaikan suhu. Selain itu gerakan pijat menimbulkan gesekan pada kulit merangsang rasa hangat dan reseptor aferen menyampaikan perubahan ini ke termostat hipotalamus. Termostat akan menghambat aktivitas adrenergik dari sistem saraf simpatik, (yang mengontrol vasokonstriksi dan tingkat metabolisme) menyebabkan vasodilatasi dan penurunan basal metabolisme rate. $\mathrm{Hal}$ ini menyebabkan peningkatan kehilangan panas melalui kulit.

Perubahan pernafasan yang sangat bervariasi dan tidak signifikan merupakan dampak fisiologis dari penuaan. Penuaan menyebabkan perubahan struktur jaringan paru, pembungkus thorax dan otot pernafasan. Terjadi penurunan 
elasitas rekoil paru. Paru menjadi lebih kecil. jumlah alveoli menurun, penurunan luas permukaan alveolar berkontribusi pada penurunan oksigenasi dalam darah. Perubahan ini menyebabkan kolapsnya alveoli di perifer sehingga terjadi ketidaksesuaian antara ventilasi paru-paru dan perfusi kapiler paru berdampak terhadap penurunan difusi oksigen dan karbon dioksida. Pada rongga thorax, terjadi osteoporosis dan kalsifikasi dari tulang iga menyebakan kekakuan dan ketegangan dan gangguan mobilitas dari iga. Perubahan ini menyebabkan penurunan pengembangan dada dan ekspansi paru maksimal berakibat kepada penurunan kerja pernafasan. Kondisi ini memberikan sinyal kepada kemoreseptor diteruskan ke medulla oblongata untuk meningkatkan atau menurunkan kecepatan ventilasi atau respirasi. Tetapi pada lansia karena semua bagian dari sistem syaraf mengalami perubahan, terjadi kehilangan sebagian dari neuron di brain steem (pons, medulla oblongata yang merupakan pusat pengatur pernafasan) yang menyebabkan pelebaran vetrikel, penurunan aliran darah ke otak, terjadi degenerasi myelin menyebabkan penurunan konduksi syaraf dan perlambatan respon pernafasan terhadap kondisi hemodinamik (Lewis, et al., 2011). Hal ini mempengaruhi perubahan kecepatan pernafasan yang bervariasi pada penelitian ini.

\section{KESIMPULAN}

Terapi swedish massage didapatkan berpengaruh signifikan terhadap peningkatan kualitas tidur hari ke VII dengan $p$ value $0,000 \quad(p<0,05)$ dan tingkat insomnia lansia hari ke VII dengan $p$ value $0,000(p<0,05)$. Hal ini menunjukkan bahwa swedish massage efektif meningkatkan kualitas tidur dan menurunkan tingkat insomnia lansia.
Terdapat pengaruh simultan usia dan pemberian terapi swedish massage selama 7 hari terhadap peningkatan kualitas tidur dan penurunan tingkat insomnia lansia dengan probabilitas $0,000(p<0,05)$.

\section{SARAN}

Bagi pelayanan keperawatan untuk dapat mempertimbangkan hasil penelitian sebagai rujukan dan acuan untuk merancang atau memodifikasi standar asuhan keperawatan pada pasien geriatri khususnya yang mengalami masalah tidur dan insomnia dalam intervensi keperawatan berupa program/ protokol terapi komplementer. Bagi pengembangan ilmu keperawatan mengintegrasikan terapi komplementer dan terapi non farmakologis dari berbagai hasil penelitian swedish massage yang telah terbukti menurunkan insomnia dan meningkatkan kualitas tidur ke dalam rencana asuhan keperawatan.

\section{DAFTAR PUSTAKA}

Canadian Sleep Society. 2012. Sleep in the Elderly When to Reassure, When to Intervene www.canadiansleepsociety.

CINAR, Sebnem \& ESER, İsmet. 2012. Effect on Sleep Quality of Swedish massage in Older Adults in Rest Home. www.deu. edu.tr/Uploade Diperoleh 12 Februari 2019.

Darmodjo, Boedhi. 2010. Geriatri (IImu Kesehatan Usia Lanjut). Jakarta; Balai Penerbit FKUI.

Departemen Kesehatan Republik Indonesia. 2013. Lansia. www.depkes.go diperoleh 12 Februari 2019.

Hellström, Amanda. 2013. Insomnia symptoms in elderly persons Assessment.

Lewis, et al. 2011 Medical Surgical Nursing. St Louis Missouri; Elsiever. 
Mosbys, Elsivier,. 2009. Nursing Videos Skill. USA: Mosbys, Elsivier.

Reed, Jan, Clarke, Charlotte. 2012. Nursing Older Adults. Glasgow : Bell \& Bell.

University of Maryland Medical Centre. 2013. Relaxation technique. http:/umm.edu. health Diperoleh 12 Februari 2019.

WHO. 2013. Definition of an older or elderly person www.who.int Diperoleh 12 Februari 2019. 